\title{
A confusing endodontic case with retrograde periodontitis.
}

\author{
Hisashi Anan*\#, Etsuko Matsuzaki*\#
}

Section of Operative Dentistry and Endodontology, Department of Odontology, Fukuoka Dental College, 2-15-1 Tamura, Sawara-ku, Fukuoka 814-0193, Japan.

${ }^{\#}$ Equally contributed

\begin{abstract}
Endodontic-periodontal lesions are often observed in clinical situations. Although endodonticperiodontal lesions are encountered, they may pose difficulties for the clinician in diagnosis and may complicate the treatment. Diagnosis is often challenging because these diseases have been primarily studied as separate entities, and each primary disease may mimic the clinical characteristics of the other disease. In this report, a simple classification of endodonticperiodontal lesions is demonstrated, and presents a case of endodontic-periodontal disease in an immature tooth with a vertical bone defect showing retrograde periodontitis in which successful results were obtained by using infected root canal treatment and apexification with Vitapex $\mathbb{R}$ containing calcium hydroxide.
\end{abstract}

Keywords: Immature tooth, Endodontic-periodontal disease, Retrograde periodontitis, Vertical bone defect, Apexification.

Accepted on October $29^{\text {th }}, 2018$

\section{Introduction}

It is well-known that apical periodontitis is caused mainly by bacteria and bacterial components from the root canal system. Periapical bone destruction is the most characteristic feature of acute purulent apical periodontitis [1,2]. In most cases, the abscess destroys the relatively thin bone cortex on the buccal or lingual side. Abscesses form under the periosteum, causing the inflammation to expand further into the surrounding soft tissue, which can result in the formation of fistula and a shift from acute apical periodontitis to chronic apical periodontitis [3].

Endodontic-periodontal disease is a relatively familiar disease; however, its etiology is not easily elucidated in daily clinical practice [4-6]. Even carefully following the highest standard of treatment will not always cure it, and refractory apical periodontitis can then develop.

Here a simple classification of endodontic-periodontal lesions is demonstrated (Figure 1):

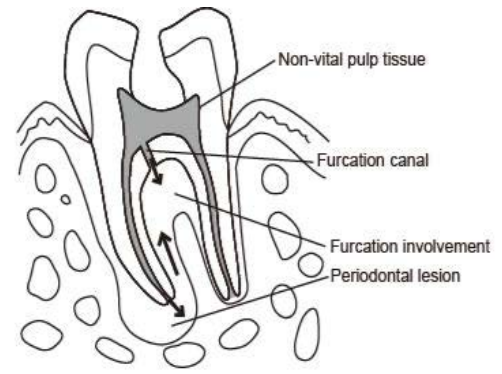

Type 1b: Primary endodontic lesion (Furcation involvement)

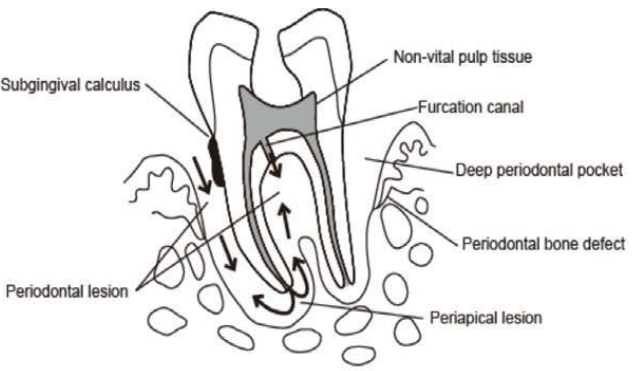

Type 3: Combined endodontic-periodontal lesion

Type 2: Primary periodontal lesion (Ascending pulpitis)

Figure 1: A simple classification of endodontic-periodontal lesions 
Type 1a: Primary endodontic lesion (Retrograde periodontitis)

Type 1b: Primary endodontic lesion (Furcation involvement)

Type 2: Primary periodontal lesion (Ascending pulpitis)

Type 3: Combined endodontic-periodontal lesion

The characteristic features of each type of endodonticperiodontal lesion are shown in Table 1. In this report, a treatment course for Type 1a along with this classification, endodontic-periodontal disease in an immature tooth with retrograde periodontitis, is demonstrated.

\section{Case Report}

A 10-year-old girl visited with the chief complaint of gingival swelling of the mandibular left premolar (Figure 2a). She was referred to the hospital for specialized care, manifesting spontaneous pain $(-)$, percussion pain $(+)$, tooth mobility $(-)$, sinus tract $(+)$, and apical pressure pain $( \pm)$ in 35. Probing Periodontal Pocket Depth (PPD) of 35 was $6 \mathrm{~mm}$, with no bleeding on probing; PPD of the other teeth were less than $2 \mathrm{~mm}$ (Figure 2b). Good oral hygiene was seen, and neither deposits of plaque nor calculus were observed in

Table 1. Differential diagnosis of endodontic-periodontal lesions

\begin{tabular}{|c|c|c|c|c|c|}
\hline & $\begin{array}{l}\text { Pulp } \\
\text { condition }\end{array}$ & Periodontal pocket & $\begin{array}{l}\text { Gutta-percha cone } \\
\text { into the sinus tract }\end{array}$ & X-ray finding & \\
\hline $\begin{array}{l}\text { Type I } \\
\text { (Primary } \\
\text { endodontic lesions) }\end{array}$ & $\begin{array}{l}\text { Non vital } \\
\text { pulp/ } \\
\text { pulp less }\end{array}$ & $\begin{array}{l}\text { A few deep pockets } \\
\text { (drainage path } \\
\text { through the } \\
\text { periodontal ligament } \\
\text { from the periapical } \\
\text { lesion ) }\end{array}$ & $\begin{array}{l}\text { The tip reach the } \\
\text { apical region }\end{array}$ & $\begin{array}{l}\text { a: Clear radiolucent area } \\
\text { along the only one side } \\
\text { root } \\
\text { (U shape) } \\
\text { b: Furcation radiolucent } \\
\text { area }\end{array}$ & $\begin{array}{l}\text { Significant periodontitis is } \\
\text { hardly seen }\end{array}$ \\
\hline $\begin{array}{l}\text { Type II } \\
\text { (Primary } \\
\text { periodontal lesions) }\end{array}$ & $\begin{array}{l}\text { Vital } \\
\text { pulp }\end{array}$ & $\begin{array}{l}\text { Extensive many } \\
\text { deep pockets }\end{array}$ & $\begin{array}{l}\text { The tip does not } \\
\text { face the root } \\
\text { apex but heads } \\
\text { toward the } \\
\text { cervicular } \\
\text { portion. }\end{array}$ & $\begin{array}{l}\text { Clear radiolucent area at } \\
\text { the marginal portion ( } \mathrm{V} \\
\text { shape) } \\
\text { Furcation radiolucent } \\
\text { area neighboring } \\
\text { marginal bone defect }\end{array}$ & $\begin{array}{l}\text { Chronic periodontitis is } \\
\text { seen } \\
\text { around neighboring teeth }\end{array}$ \\
\hline $\begin{array}{l}\text { Type III } \\
\text { (Combined } \\
\text { Endodontic periodontal } \\
\text { lesions) }\end{array}$ & $\begin{array}{l}\text { Non vital } \\
\text { pulp/ } \\
\text { pulp less }\end{array}$ & $\begin{array}{l}\text { Extensive many } \\
\text { deep pockets }\end{array}$ & $\begin{array}{l}\text { The tip easily } \\
\text { reach the apical } \\
\text { region }\end{array}$ & $\begin{array}{l}\text { Clear radiolucent area } \\
\text { throughout the root }\end{array}$ & $\begin{array}{l}\text { Chronic periodontitis is } \\
\text { seen } \\
\text { around neighboring teeth }\end{array}$ \\
\hline
\end{tabular}

a

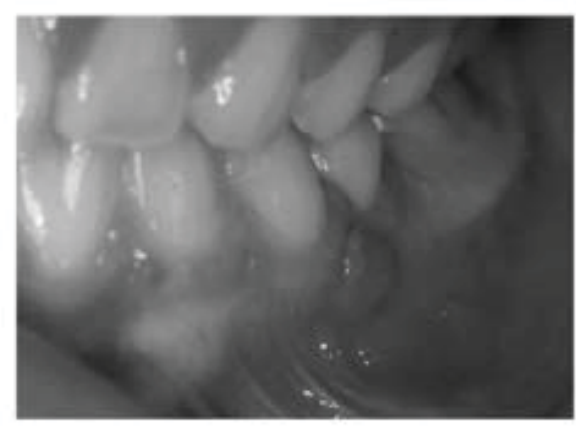

C

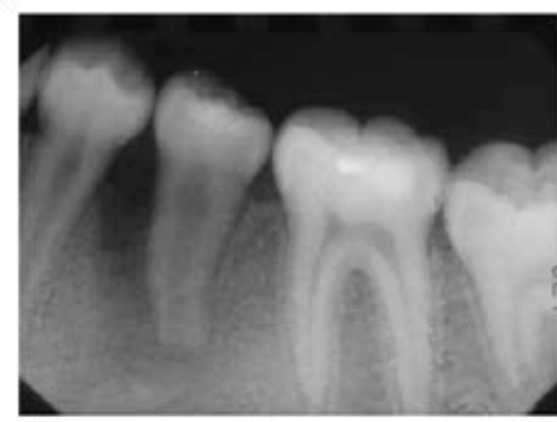

b

\begin{tabular}{|c|c|c|c|}
\hline mobility & \multicolumn{3}{|c|}{0} \\
\hline BOP & - & - & - \\
\hline $\begin{array}{c}\text { Lingual } \\
\text { PD }\end{array}$ & 2 & 1 & 2 \\
\hline tooth & \multicolumn{3}{|c|}{35} \\
\hline $\begin{array}{c}\text { Buocal } \\
\text { PD }\end{array}$ & 6 & 2 & 2 \\
\hline BOP & - & - & - \\
\hline
\end{tabular}

BOP: bleeding on probing PD: probing depth

Figure 2. Findings of tooth 35 at initial visit

a: Swelling and erosion of buccal gingiva between 34 and 35 were observed.

$b$ : Data of periodontal examination

c: X-ray film showed prominent radiolucent area extending to the root apex in the mesial site of 35 . 
the pocket. Radiographic examination revealed a prominent radiolucent area extending to the root apex in the mesial site of 35 (Figure 2c). A radiolucent area in the central portion of the occlusal surface was observed (Figure 3a). A gutta-percha cone through the sinus tract was used to close the root apex (Figure $3 b$ ). Out of all the teeth, the vertical bone defect was only observed at the mesial site of 35 (Figure 4).

Infected root canal treatment and apexification were implemented based on a clinical diagnosis of Type 1a endodonticperiodontal disease (retrograde periodontitis) caused by a fracture of the central cusp. After infected root canal treatment, reduction of radiolucency and bone tissue regeneration were continuously observed at the mesial site of 35 (Figures 5 and 6(a-d)).Root canal filling was performed because a remarkable recovery of bone tissue was observed from the apex to the marginal portion and the open apex was closed nine months after the infected root canal treatment (Figure 7a).

Two years and four months after the root canal filling, no radiolucent area was observed and the alveolar bone height showed the same level as the neighboring teeth. The prognosis has been favorable, with a clear laminar dura at the mesial site of 35 (Figures $7 \mathrm{~b}$ and $7 \mathrm{c}$ ).

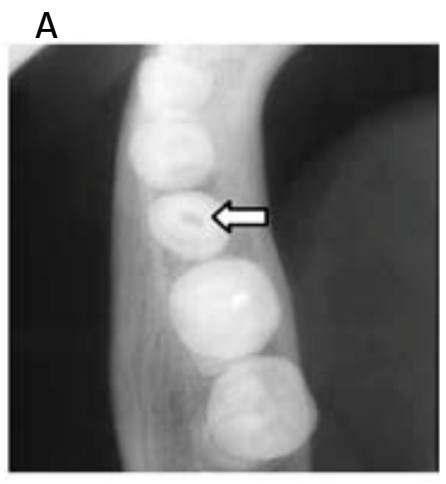

Figure 3. X-ray findings of tooth 35 at initial visit

a: The radiolucent area (arrow) in the central portion of the occlusal surface was observed.

b: Gutta-percha cone through sinus tract was close to the root apex.

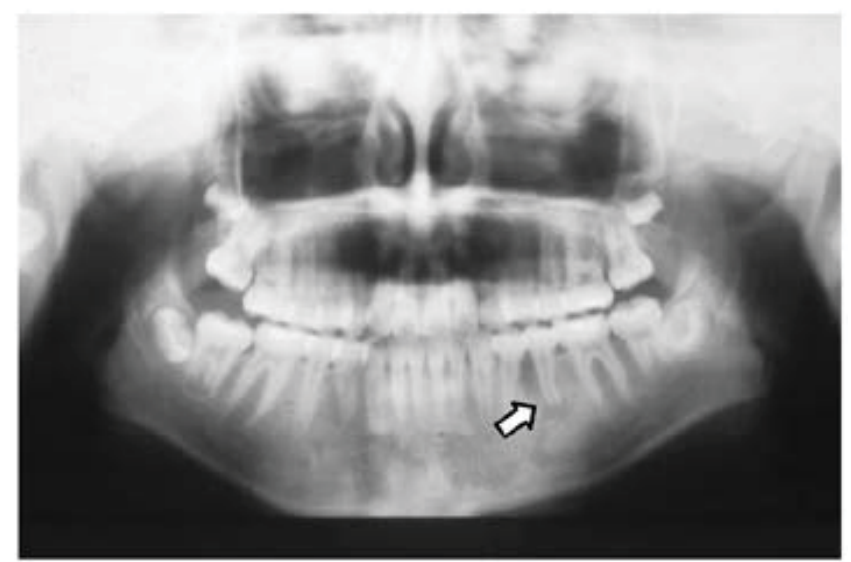

Figure 4. Ortho-pantomography finding at initial visit the vertical bone defect (arrow) was only observed at the mesial site of 35

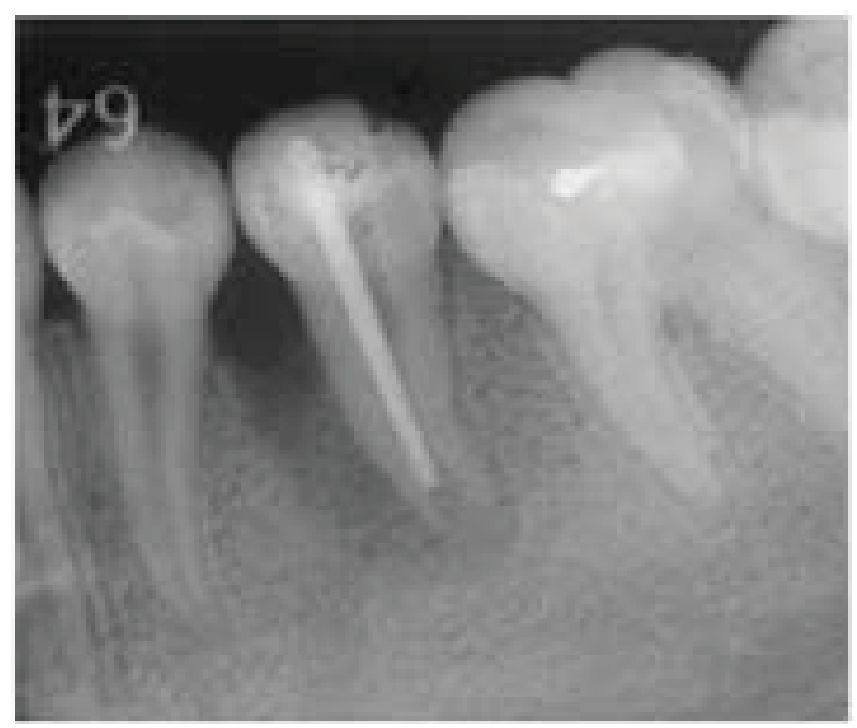

Figure 5. Findings of tooth 35 of infected root canal treatment at initial visit a gutta-percha cone was located under the open apex.

\section{Discussion}

The central nodule that is commonly found in the mandibular second premolar is a conical or short rod like small protrusion seen in the central part of the occlusal surface. As a result, when this protrusion breaks during occlusion, the pulp is exposed, which may cause apical periodontitis from pulpitis, so clinical attention is required. It has been generally reported that bacterial infection spreads to the pulp cavity due to a coronal fracture caused by trauma, and suppurative inflammation often happens in the dental pulp tissue. It has also been suggested that pulpal necrosis occurs as a sequel of pulpitis or traumatic injury, and then apical periodontitis is caused by bacteria and bacterial products from the root canal system [3]. Although rare, it has been demonstrated that periapical inflammation can develop into retrograde periodontitis [7]. In this case, a deep narrow pocket was seen at just one aspect of the root surface and open to the gingival sulcus or the bottom of the existing periodontal pocket.

In general, chronic periodontitis is a common plaqueinduced periodontal infection that shows connective attachment loss followed by activation of bone resorption. Furthermore, in progressive periodontitis, wedge-shaped vertical bone defects, many deep periodontal pockets and the accumulation of large amounts of plaque are observed [8].

Because the patient in this case was 10 years old, it was hard to believe that she could be suffering from chronic periodontitis at this age. Additionally, hardly any accumulation of plaque was observed in the gingival sulcus. A horizontal bone defect image was observed at the mesial side in the X-ray findings and a periodontal pocket of $6 \mathrm{~mm}$ was only seen in the buccal mesial side of the diseased tooth root. This periodontal pocket disappeared quickly after the root canal treatment, and the X-ray findings revealed that bone tissue had recovered to a healthy level after root canal 
a

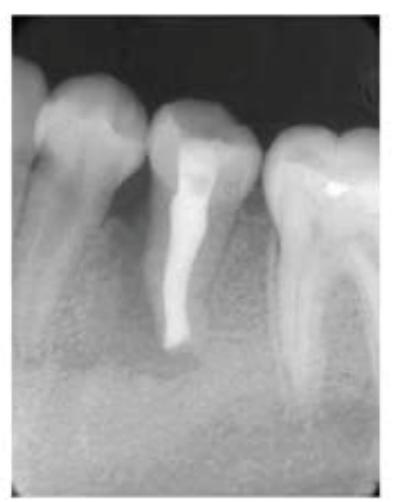

b

\begin{tabular}{|c|c|c|c|}
\hline mobility & \multicolumn{3}{|c|}{0} \\
\hline BOP & - & - & - \\
\hline $\begin{array}{c}\text { Lingual } \\
\text { PD }\end{array}$ & 2 & 1 & 2 \\
\hline tooth & \multicolumn{3}{|c|}{35} \\
\hline $\begin{array}{c}\text { Buocal } \\
\text { PD }\end{array}$ & 2 & 1 & 2 \\
\hline BOP & - & - & - \\
\hline
\end{tabular}

C

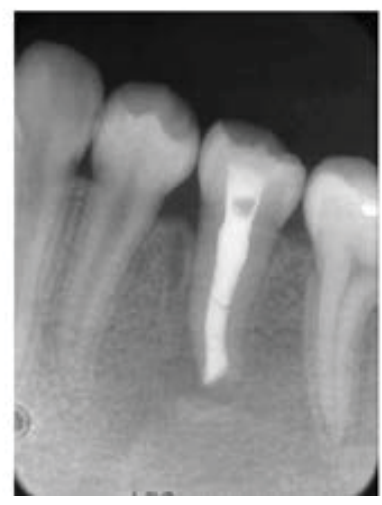

d

\begin{tabular}{|c|c|c|c|}
\hline mobility & \multicolumn{3}{|c|}{0} \\
\hline BOP & - & - & - \\
\hline $\begin{array}{c}\text { Lingual } \\
\text { PD }\end{array}$ & 2 & 1 & 2 \\
\hline tooth & \multicolumn{4}{|c|}{35} \\
\hline $\begin{array}{c}\text { Buccal } \\
\text { PD }\end{array}$ & 2 & 1 & 2 \\
\hline BOP & - & - & - \\
\hline
\end{tabular}

Figure 6. Findings of tooth 35 during apexification

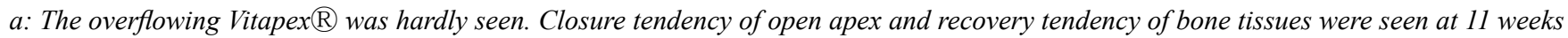
after infected root canal treatment.

b: Data of periodontal examination (11 weeks)

$c$ : The improvement and regeneration of bone tissues were observed at 5 month after treatment.

d: Data of periodontal examination (5 months)

a

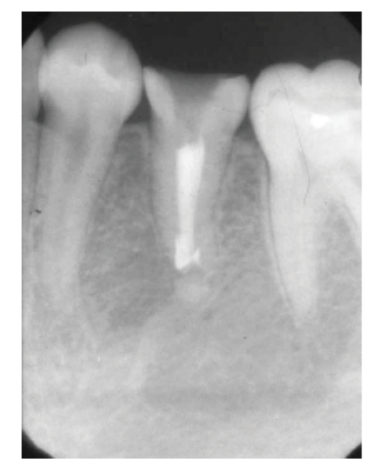

b

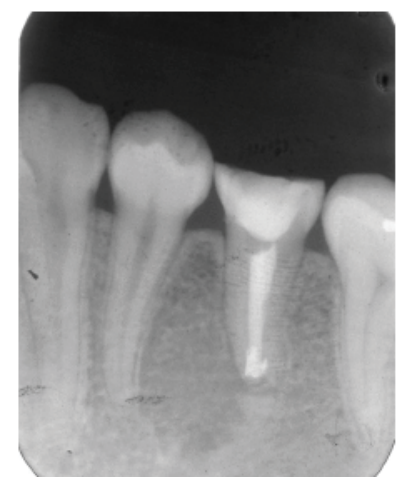

C

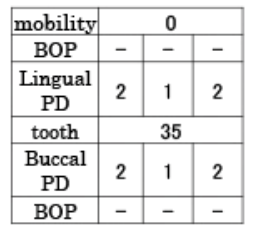

Figure 7. Findings of tooth 35 after root canal filling

a: A remarkable recovery of bone tissues were observed from the apex at root canal filling, 9 months after infected root canal treatment.

b: There were no radiolucent area and the clarity of laminar dura at the mesial site of 35 at 2 year 4 months after root canal filling.

c: Data of periodontal examination (2 year 4 months)

filling. From these findings, it is inferred that the resorption image of the alveolar bone at the marginal portion observed in this case was a different lesion from the true marginal periodontitis characterized by the attachment loss.

It is well-known that the first choice of treatment for Type 1 endodontic-periodontal disease caused by apical periodontitis is infected root canal treatment [4-6]. In addition, intervention by periodontal treatment after followup should be considered. Conversely, it has been suggested that root formation and apical closure are possible in immature teeth as long as the Herdwig's epithelial sheath survives, even when the pulp is infected and necrosed $[9,10]$. It is thus important to be careful not to damage the periodontal tissue of the apical portion by over instrumentation and over filling beyond the apical foramen.

A prerequisite that forms the basis of infected root canal treatment appears to be not to damage the apical periodontal tissue but to activate its self-repairing ability by eliminating inflammatory factors in the root canal and to enhance the healing mechanisms of the periapical region. It is therefore necessary to keep the Vitapex ${ }^{\circledR}$ containing calcium hydroxide inside the root canal. Elongation of the root and closure of the open apex were observed as a result of root canal treatment in which the work length was set so that the calcium hydroxide preparation did not come into direct contact with the apical periodontal tissue [11-14]. In this case, a slight elongation of the apical apex was observed two years and four months after root canal filling without intervention by periodontitis treatment. In recent years, the possibility of hard tissue formation resulting from differentiation of the Stem Cells of the Apical Papilla (SCAP) has been suggested $[15,16]$. It is thought that elongation of the apical root and healing of the alveolar bone were induced by providing an effective environment for restoring the function 
of the Herdwig's epithelial sheath and activating the SCAP. Recently, Regenerative Endodontic Therapy (RET) has attracted attention [17]. It was reported that RET and apexification achieved a comparable outcome in regard to the resolution of symptoms and apical healing in the treatment of immature teeth with the periapical lesion [18].

It has been demonstrated that the pathway of endodontic inflammation is through the apical foramen, furcation canals, and lateral accessory canals to the periodontal ligament in the endodontic-periodontal lesions [3]. In addition, endodonticperiodontal diseases are caused by various factors such as perforation and root fracture [9-22]. Therefore, the clinician needs to bear in mind that the successful outcome is based on accurate diagnosis during the treatment of the confusing endodontic-periodontal problem.

\section{Conclusion}

The results confirm the importance of accurate examination and diagnosis using clinical examination and precise observation of the X-ray findings in the treatment of endodontic-periodontal disease (primary endodontic lesion) showing retrograde periodontitis and open apex.

\section{Acknowledgement}

The authors confirm that there are no conflicts of interest related to this study.

\section{References}

1. Kawashima N, Suzuki N, Yang G, et al. Kinetics of RANKL, RANK and OPG expression in experimentallyinduced rat periapical lesions. Oral Surg Oral Med Oral Pathol Oral Radiol Endod. 2007;103(5):707-11.

2. Stashenko P. The role of immune cytokines in the pathogenesis of periapical lesions. Endodo Dent Traumatol.1990;6(3):89-96.

3. Lin LM, J. Huang GT. Pathobiology of apical periodontitis. Hargreaves KM, Berman LH, eds. Cohen's Pathways of the Pulp, 11th ed. St. Louis: Mosby;2016.

4. Rateitschak KH, Rateitschak EM, Wolf HF, et al. Color Atlas of Dental Medicine, Periodontology. PeriodonticsEndodontics. New York: Thieme Medical Publishers Inc; 1989.

5. Weine FS. Endodontic-periodontal problems. Endodontic therapy, 6th ed. St. Louis: Mosby; 2004.

6. Kerns DG, Glickman GN. Endodontic and periodontal interrelationships. Hargreaves KM, Cohen S. Cohen's pathways of the pulp, 10th ed. St. Louis: Mosby; 2011.

7. Al-Fouzan KS. A new classification of endodonticperiodontal lesions. Int J Dent. 2014;2014:1-5.
8. Armitage GC. Diagnosis and classification of periodontal diseases. Rose LF, Brian Mealey B, Genco R. Periodontics: Medicine, Surgery and Implants, 1 st ed. St. Louis: Mosby; 2004.

9. Michanowicz JP, Michanowicz AE. A conservative approach and procedure to fill an incompletely formed root using calcium hydroxide as an adjunct. J Dent Child. 1967;34(1):42-7.

10. Tenca JI, Tsamtsouris A. Continued root end development: apexogenesis and apexification. J Pedon. 1978;2(2):14457.

11. Ghose LJ, Bagdady VS, Hikmat YM. Apexification of immature apices of pulpless permanent anterior teeth with calcium hydroxide. J Endod. 1987;13(6):285-90.

12. Morfis AS, Siskos G. Apexification with the use of calcium hydroxide: a clinical study. J Clin Pediatr Dent. 1991;16(1):13-9.

13. Sheehy EC, Roberts GJ. Use of calcium hydroxide for apical barrier formation and healing in non-vital immature permanent teeth: A review. Br Dent J. 1997;183(7):241-6.

14. Rafter M. Apexification: a review. Dent Traumatol. 2005;21(1):1-8.

15. Sonoyama W, Yamaza T, Tuan RS, et al. Characterization of apical papilla and its residing stem cells from human immature permanent teeth-a pilot study. J Endod. 2008;34(2):166-71.

16. Chrepa V, Pitcher B, Henry MA, et al. Survival of the apical papilla and its resident stem cells in a case of advanced pulpal necrosis and apical periodontitis. J Endod. 2017;43(4):561-7.

17. Murray PE, Garcia-Godoy F, Hargreaves KM. Regenerative endodontics: a review of current status and a call for action. J Endod. 2007;33(4):377-90.

18. Lin J, Zeng Q, Wei X, et al. Regenerative Endodontics Versus Apexification in Immature Permanent Teeth with Apical Periodontitis: A Prospective Randomized Controlled Study. J Endod. 2017;43(11):1821-7.

19. Gahanbari H, Ghoggusi J, Mohtasham N. A comparison between amalgam and MTA in repairing furcal perforations. J Dent. 2008;5(3):115-9.

20. Shahi S, Rahimi S, Hasan M, Shiezadeh V, Abdolrahimi M. Sealing ability of mineral trioxide aggregate and Portland cement for furcal perforation repair: A protein leakage study. J Oral Sci. 2009;51(4):601-6.

21. Tang L, Zhou XD, Wang Y, et al. Detection of vertical root fracture using cone beam computed tomography: Report of two cases. Dent Traumatol. 2011;27(6):484-8. 
22. Edlund M, Nair MK, Nair UP. Detection of vertical root fracture using cone beam computed tomography: A clinical study. J Endod. 2011;37(6):768-72.

\section{*Correspondence to:}

Hisashi Anan

Section of Operative Dentistry and Endodontology, Department of Odontology, Fukuoka Dental College, 2-15-1 Tamura, Sawara-ku, Fukuoka 814-0193, Japan,

Tel: +8192801 0411;

Fax +81928719494;

E-mail: hanan@college.fdcnet.ac.jp

Etsuko Matsuzaki

Section of Operative Dentistry and Endodontology,

Department of Odontology,Fukuoka Dental College, 2-15-1 Tamura, Sawara-ku, Fukuoka 814-0193, Japan,

Tel: +8192801 0411;

Fax +81928719494;

E-mail: matsuzaki@college.fdcnet.ac.jp 